\title{
OBSERVATION ON BREAST SELF EXAMINATION(BSE) FOR EARLY DETECTION OF BREAST CANCER IN STUDENTS AT HEALTH FACULTY OF MH. THAMRIN UNIVERSITY
}

\author{
Rosa Susanti ${ }^{1)}$, Dewi Suri Damayanti ${ }^{2)}$ \\ Email: rosasusanti@thamrin.ac.id \\ ${ }^{1,2}$ Prodi DIII Kebidanan Universitas, Fakultas Kesehatan, Mohammad Husni Thamrin, \\ Jl. Raya Pondok Gede No. 23-25 Kramat Jati - Jakarta Timur 13550
}

\section{Article Information}

Received:

October 21, 2019

Revised:

December 26, 2019

Accepted:

January 19, 2020

Available online:

January 23, 2020

\begin{abstract}
The prevalence of cancer had increased in the last five years. According to the Basic Health Research (Riskesdas) in 2018, the prevalence of cancer in Indonesia reaches 1.79 of 1000 population, up from 2013 as many as 1.4 of 1000 population. The study aimed to describe Breast Self Examination (BSE) for Early Detection of Breast Cancer. Study Stages (i) preparation: disseminating questionnaires through Google form, (b) identifying respondents who have done and never conducted with BSE (c) determining population (d) sampling. Stage (ii) implementation: data collection using a questionnaire and checklist. Stage (iii) Analysis bivariate with Chi-square. Respondents in this study were 100 people. The result of this study that respondents whom BSE Practice well $42 \%$ and poorly $58 \%$ and there is a significant relationship between information exposure to BSE Practice.
\end{abstract}

Keywords: Behaviour, Practice, Breast Self Examination (BSE)

\section{Introduction}

Cancer still is a severe health problem in Indonesia. Ministry of Health (Kemkes) said the prevalence of cancer had increased in the last five years. According to the Basic Health Research (Riskesdas) in 2018, the prevalence of cancer in Indonesia reaches 1.79 per 1000 population, up from 2013 at 1.4 per 1000 population. Studies also found that the highest prevalence was in Yogyakarta, 4.86 per 1000 population, followed by West Sumatra 2.47, and Gorontalo 2.44. Other data, Globocan in 2018, showed that the incidence of cancer in Indonesia was 136.2 per 100,000 population. This data put Indonesia in eighth place with the most cases in Southeast Asia and ranked 23rd in Asia. The highest incidence rate in men was lung cancer at 19.4 per 100,000 population with an average mortality of 10.9 per 100,000 population. Followed by liver cancer with an incidence of 12.4 per 100,000 population, and an average death rate of 7.6 per 100,000 population. Whereas in women, the highest cause was breast cancer at 42.1 per 100,000 population with an average mortality of 17 per 100,000. After that, cervical cancer was 23.4 per 100,000 population, with an average mortality of 13.9 per 100,000 population..$^{[1]}$

People with breast cancer had been found at a young age, and even a few were teenage girls of fourteen detected with tumours in their breast, whereas the tumours can potentially become cancerous if not detected early. ${ }^{[2]}$

Early breast cancer screening can be done by doing breast self-examination or known as BSE. BSE is an accessible examination that can be done by every woman and by themself. This action is essential because almost $85 \%$ of 
abnormalities in the breast were found the first time by sufferers through BSE correctly. ${ }^{[3]}$ Through BSE, about $95 \%$ of women diagnosed with early breast cancer can survive more than five years after being diagnosed..$^{[4]}$

The results of the study by Ninik et al. said that only $10 \%$ of nursing students practised $\mathrm{BSE}^{[5]}$, while the results of Fitria's showed that $56 \%$ of Diploma III students do BSE and 44\% did not. ${ }^{[6]}$ Rosa's study found that the respondents who had done BSE were $88.1 \%$, and those who had never done BSE were $11.9 \%$. Rosa stated, after observing using phantom, the respondents who had done BSE were known that only $43.6 \%$ did BSE correctly, and $56.4 \%$ did BSE incorrectly. ${ }^{[7]}$ Based on the description above, We were interested in conducting a study on Observation of BSE Behavior and Factors Related to BSE Practices in Students at the Faculty of Health, University of MH. Thamrin.

\section{Method}

The study used a quantitative method with a descriptive approach. This study used a cross-sectional approach to obtain a complete picture of Breast Selfexamination (BSE) for the early detection of breast cancer in students. The stages of this study consisted of three stages: (i) preparation, (a) distributed questionnaires through Google forms to all regular students of the Health Faculty of MH. Thamrin University. The questions contain general questions and experience in conducting BSE (b) through Google form; we identify the respondents who have done and never done BSE (c) determining the population, i.e. all students of who fill out the Google form and answer that they have done BSE which 273 students. (d) Taking a sample with a systematic random sampling technique. Stage (ii) Implementation, the data collected using a questionnaire and checklist used to observe BSE behaviour and obtained a sample of 100 students. Stage (iii) Data analysis to identify the respondents who done it correctly or not according to BSE checklist and identifying factors related to BSE and dominant factors that influence BSE practice. The data used in this study were primary, namely the from questionnaires and observation of BSE practice using phantom. The analysis techniques used were univariate and bivariate (Chi-Square Test).

\section{Result and Discussion}

Table 1 Description of BSE Practices in Students at Health Faculty of MH. Thamrin University

\begin{tabular}{ccc}
\hline $\begin{array}{c}\text { BSE } \\
\text { Practice }\end{array}$ & f & \% \\
\hline Correctly & 42 & 42 \\
Incorrectly & 58 & 58 \\
\hline
\end{tabular}

Univariate analysis results in this study found that respondents who did BSE practice correctly were $42 \%$, and $58 \%$ were lacking.

Fitria's study showed that $56 \%$ of

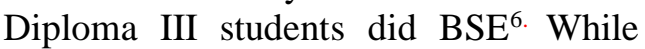
Rosa's study showed that respondents who had done BSE were $88.1 \%$, and after observing using phantom it was known that respondents who had done BSE correctly were $43.6 \%$ and $56.4 \%$ respondents found lacking. ${ }^{[7]}$

Table 2Breast Self-Examination Steps

\begin{tabular}{ccc}
\hline BSE Steps & f & \% \\
\hline 1 & 82 & $82 \%$ \\
2 & 59 & $59 \%$ \\
3 & 58 & $58 \%$ \\
4 & 32 & $32 \%$ \\
5 & 15 & $15 \%$ \\
6 & 18 & 185 \\
7 & 47 & $47 \%$ \\
8 & 32 & $32 \%$ \\
9 & 21 & $21 \%$ \\
10 & 74 & $74 \%$ \\
11 & 77 & $77 \%$ \\
total & 100 & $100 \%$ \\
\hline
\end{tabular}

$82 \%$ respondents practice correctly in the first step, i.e. looking at the breasts and look at in the mirror if there were changes in shape, size, nipples or folded the skin, sunken skin; checking for swelling, monitor body temperature or pain in one or both breasts were not conducted by $18 \%$ respondents. $59 \%$ of 
respondents did the second step correctly, i.e. looking at their nipples and paying attention to the size, shape and direction. Checking for rashes or sores and discharge from the nipples were not conducted by $41 \%$ respondents. There were $58 \%$ of respondents did correctly in the third step, i.e. lifting both arms above the head and looking at both breasts. Noting whether there were differences and there were $42 \%$ do not practice it. There were $32 \%$ respondents did correctly in the fourth step, which is putting both hands on the waist and looking back at the breasts if there were differences and $68 \%$ did not do the practice. There were $15 \%$ of respondents who did it correctly in the fifth step, i.e. bending to see if both breasts were hanging in a balanced way, and $85 \%$ did not practice it.

The correct practice in the sixth step is lying down and place the pillow under the left shoulder. $18 \%$ were putting the left arm over the head, and $82 \%$ did not. The correct practice in the seventh step is using the index, middle and ring fingers; palpating the entire breast, starting from the uppermost edge of the breast, using a spiral technique where 47\% respondents and 53\% did not. The correct practice in the eight steps is using the thumb and index finger to press on the nipple is there any discharge, if there was is it clear, cloudy or bleeding. $32 \%$ of respondents were practising it, and 68\% did not. Correct practice in the ninth step is repeating the steps before for the right breast, $21 \%$ of respondents were doing it, and $79 \%$ did not. The correct practice in the tenth step is sitting down and lift the left arm at shoulder height, and right hand palpate the base of the breast by pressing along the outer side of the left pectoral muscle while gradually moving the fingers towards the axilla. Checking for lymph node enlargement (lymph nodes) or pain; $74 \%$ of respondents were practising it, and $26 \%$ did not. In the eleventh step, $77 \%$ did it correctly by repeating this step for the right breast.

The data above show that most BSE steps taken by respondents were step
1, 10 and 11. The BSE steps which were not done were lying down because the respondent thought that by doing it standing, it was correct, while according to the theory, the correct step should be done by lying down. When lying down, the breasts were in a state of relaxing and thin, making it easier to find lumps. The students make the second mistake were nipple massaging. Some respondents did not know that in BSE need to do nipple massage, and also they feel uncomfortable when doing nipple massage. According to the theory, one of the signs and symptoms of Ca Mammae was found blood or pus discharge from the nipple. Respondents who did BSE regularly every month were $30 \%$ and those who did not were $70 \%$. Based on punctuality, $27 \%$ were punctual, and $73 \%$ were not. This result is in line with Susanti's study, which states that $25.7 \%$, respondents do BSE regularly every month while respondents who did it regularly and punctual only $11.9 \%$. ${ }^{[7]}$

Table 3 Relationship Between Attitude and BSE Practice

\begin{tabular}{lcccccc}
\hline \multirow{2}{*}{ Attitude } & \multicolumn{4}{c}{ BSE Practice } & p-value \\
\cline { 2 - 5 } & \multicolumn{2}{c}{ Correctly } & \multicolumn{3}{c}{ Incorrectly } & \\
\cline { 2 - 5 } & $\mathbf{f}$ & $\boldsymbol{\%}$ & $\mathbf{f}$ & $\boldsymbol{\%}$ & \\
\hline Positive & 17 & 50 & 17 & 50 & $\mathbf{0 . 3 2 4}$ \\
Negative & 25 & 37.9 & 41 & 62.1 & \\
\hline
\end{tabular}

The results of this study found that the relationship between attitude and BSE practices showed a positive attitude with $50 \%$ BSE practice, more significant than the negative attitude (37.9\%). The statistical analysis results obtained pvalue 0.324 , which means there is no significant relationship between attitude and BSE practice. Accordance with Susanti and Ekanita stated that there was a relationship between attitude and BSE practice. There were $43.8 \%$ of respondents showed their positive attitudes, but statistically, showed that there was no significant relationship (pvalue $=1,167) \cdot{ }^{[7,8]}$

Table 4 Relationship Between Information Exposure with BSE Practice 


\begin{tabular}{|c|c|c|c|c|c|}
\hline \multirow{3}{*}{$\begin{array}{c}\text { Information } \\
\text { Exposure }\end{array}$} & \multicolumn{4}{|c|}{ BSE Practice } & \multirow{3}{*}{$\begin{array}{c}\text { p- } \\
\text { value }\end{array}$} \\
\hline & \multicolumn{2}{|c|}{ Correctly } & \multicolumn{2}{|c|}{$\begin{array}{c}\text { Incorrectl } \\
\mathbf{y}\end{array}$} & \\
\hline & $\mathbf{f}$ & $\%$ & f & $\%$ & \\
\hline Exposed & 21 & 55.3 & 17 & 44.7 & $\mathbf{0 , 0 3 5}$ \\
\hline Unexposed & 21 & 33.9 & 41 & 66.1 & \\
\hline
\end{tabular}

radio, magazines/newspapers, social networking / messangers / internet.

A teenager who had received information about the importance of BSE would tend to practice BSE. Sugiyanti et al. (2013) stated that there was a significant relationship between media

In this study, it is known that the relationship between information exposure and BSE practices shows that $33.9 \%$ respondents who unexposed group but still do BSE correctly, and respondents who were exposed with information and do BSE correctly were $55.3 \%$. Statistical analysis obtained pvalue $=0.035$, which means there is a significant relationship between information exposure with BSE practice. This result is in line with Imeldyanti's study, which stated that there were 4,122 times that people who were exposed by the media would do BSE. ${ }^{[9]}$

Various forms of mass media such as television, radio, newspapers, magazines and others have a significant impact on people's opinions and beliefs. The mass media provides suggestive messages that could direct someone's opinion. The existence of new information about the existence of an issue gives a new cognitive basis in forming attitudes. The stronger the messages will provide a more practical basis in assessing things, formed attitudes in certain direction3. Mass media in the form of print and electronic media. In delivering messages, they carry suggestive messages that can influence our opinions. If the suggestive message that is conveyed is strong enough, it will provide an adequate basis in assessing something, to form a certain attitude. ${ }^{[3]}$

Someone with more information sources will have broader knowledge Mesdiana et al. 2012 in her study showed that the majority of respondents 38 people (84.44\%) obtained information about breast cancer and BSE which originated from > 3 information media. Only 3 respondents $(6.66 \%)$ came from $<2$ information media. The source information in this study were television, access and BSE practice (p-value $0.001) \cdot{ }^{[10]}$

Table 5 Relationship Between Knowledge with BSE Practice

\begin{tabular}{|c|c|c|c|c|c|}
\hline \multirow{3}{*}{ Knowledge } & \multicolumn{4}{|c|}{ BSE Practice } & \multirow[t]{3}{*}{ p-value } \\
\hline & \multicolumn{2}{|c|}{ Correctly } & \multicolumn{2}{|c|}{ Incorrectly } & \\
\hline & $\mathbf{f}$ & $\%$ & $\mathbf{f}$ & $\%$ & \\
\hline Excellent & 15 & 35.7 & 27 & 64.3 & 0.380 \\
\hline Less & 27 & 46.6 & 31 & 53.4 & \\
\hline
\end{tabular}

Knowledge is essential in forming people behaviour. In this study, found that respondents who had excellent knowledge, most of them did not practice BSE correctly (64.3\%), so did respondent who had less knowledge (53.4\%). Statistically showed that the p-value was 0.380 , which means there was no significant relationship between knowledge and BSE Behavior. Fitriyanti and Septiani stated the same, in their study showed that there was no relationship between knowledge and practice BSE. ${ }^{[7,11]}$ This situation can be found due to the knowledge obtained by respondents about BSE was not applied daily, only for limited knowledge.

Table 6 Relationship Between Family

\begin{tabular}{llllll}
\multicolumn{4}{c}{$\begin{array}{c}\text { Encouragment with BSE Practice } \\
\text { Encouragmenty }\end{array}$} & \multicolumn{4}{c}{ BSE Practice } & p- \\
\cline { 2 - 5 } & \multicolumn{2}{c}{ Correctly } & \multicolumn{2}{c}{ Incorrectly } & value \\
\cline { 2 - 5 } & f & \% & f & \% & \\
\hline Encouraged & 21 & 53.8 & 18 & 46.2 & $\mathbf{0 . 0 8 7}$ \\
Unencouraged & 21 & 34.4 & 40 & 65.6 & \\
\hline
\end{tabular}

Relation of family encouragement with BSE Practice showed that $53.8 \%$ of respondent encouraged by their family, it is higher than the respondent who did not get it from their family (34.4\%). Statistical test results obtained p-value 0.087 , which means there is no significant relationship between family support with BSE practice. According to Suralaga, even though the respondents encouraged by 
their family, they only limited it to information about the benefit of BSE. They did not understand the steps and the reason why they should do those steps.

Table 7 Relationship Between Friends Encouragment with BSE Practice

\begin{tabular}{llllll}
\hline \multirow{2}{*}{$\begin{array}{l}\text { Friends } \\
\text { Encouragment }\end{array}$} & \multicolumn{3}{c}{ BSE Practice } & \multirow{2}{*}{ p- } \\
\cline { 2 - 5 } & $\begin{array}{c}\text { Correctl } \\
\text { value }\end{array}$ & \multicolumn{2}{c}{ Incorrectl } & \\
& \multicolumn{2}{c}{$\mathbf{y}$} & \multicolumn{2}{c}{ y } & \\
\cline { 2 - 5 } & $\mathbf{f}$ & $\boldsymbol{\%}$ & $\mathbf{f}$ & $\boldsymbol{\%}$ & \\
\hline Encouraged & 24 & 52.2 & 22 & 47.8 & $\mathbf{0 . 0 8 9}$ \\
Unencouraged & 18 & 33.3 & 36 & 66.7 & \\
\hline
\end{tabular}

Family and friends who have had BSE practices have a role in encouraging. In this study found that most respondent who encouraged by their friend and did BSE correctly $(52.2 \%) .{ }^{(6)}$ Moreover, most respondents who were lacking in BSE practice; most of them did not have their friend encouragement. Statistical test results show that there was no significant relationship between friends encouragement and BSE practice ( $p$ value 0.089). ${ }^{[7]}$

Table 8 Relationship Between Fathers' Education with BSE Practice

\begin{tabular}{|c|c|c|c|c|c|}
\hline \multirow{4}{*}{$\begin{array}{c}\text { Fathers' } \\
\text { Education }\end{array}$} & \multirow{2}{*}{\multicolumn{4}{|c|}{ BSE Practice }} & \multirow{4}{*}{$\begin{array}{c}\text { p- } \\
\text { value }\end{array}$} \\
\hline & & & & & \\
\hline & \multicolumn{2}{|c|}{$\begin{array}{c}\text { Correctl } \\
\mathbf{y} \\
\end{array}$} & \multicolumn{2}{|c|}{$\begin{array}{c}\text { Incorrectl } \\
\mathbf{y} \\
\end{array}$} & \\
\hline & f & $\%$ & $\mathbf{f}$ & $\%$ & \\
\hline Higher & 12 & 48 & 13 & 52 & 0.640 \\
\hline Lower & 30 & 40 & 45 & 60 & \\
\hline
\end{tabular}

Statistically obtained p-value 0.640 , which means there is no significant relationship between fathers' education with BSE practice. This result is in line with Fitriyanti's study, stating that there was no significant relationship between fathers' education with BSE practice. ${ }^{[6]}$

Table 9 Relationship Between Mothers' Education with BSE Practice

\begin{tabular}{|c|c|c|c|c|c|}
\hline \multirow{3}{*}{$\begin{array}{l}\text { Mothers' } \\
\text { Education }\end{array}$} & \multicolumn{4}{|c|}{ BSE Practice } & \multirow{3}{*}{$\underset{\text { value }}{\text { p- }} 5$} \\
\hline & \multicolumn{2}{|c|}{ Correctly } & \multicolumn{2}{|c|}{ Incorrectly } & \\
\hline & f & $\%$ & f & $\%$ & \\
\hline & 10 & 47.6 & & 52.4 & 0.735 \\
\hline Lowe & 32 & 40.5 & 47 & 59.5 & \\
\hline
\end{tabular}

In this study show that the mothers' respondent with higher or lower education did not have significant differences shown from the $\mathrm{p}$-value is 0.735 . This result is in line with Fitriyani that there was no significant relation between mothers' education with BSE practice. ${ }^{[6]}$

Table 10 Relationship Between Breast Cancer History with BSE Practice

\begin{tabular}{llllll}
\hline \multirow{2}{*}{$\begin{array}{c}\text { Breast } \\
\text { cancer } \\
\text { history }\end{array}$} & \multicolumn{4}{c}{ BSE Practice } & p- \\
\cline { 2 - 5 } & Correctly & \multicolumn{2}{c}{ Incorrectly } & value \\
\hline Yes & 1 & 50 & f & \% & \\
No & 41 & 41.8 & 57 & 58.2 & \\
\hline
\end{tabular}

Table 10 shows that there was no significant relationship between breast cancer history and BSE practice ( $\mathrm{p}$-value 1.000). Two respondents had breast cancer history in their family, but only one respondent who did BSE. It might be found because the respondent had a perspective that BSE could prevent or detect breast cancer earlier. Susanti state that there was no significant relationship between family history of breast cancer with BSE practice. ${ }^{[7]}$ Fitriyanti also stated that there was no significant between family history of breast cancer with BSE practice. ${ }^{[6,13]}$

\section{Conclusion}

Respondents who did BSE practice well were $42 \%$, and $58 \%$ were lacking. From observation, it was found that the correct steps taken by respondents in the BSE practice were step 1 . There was a significant relationship between information exposure with $\mathrm{BE}$ practice (p-value $=0.035)$. From this study, we suggest to provide training or practising on BSE. Need to conduct this study on different places with different characters and factors.

\section{. Acknowledgement}

Praises and gratitude to Allah SWT, who has bestowed His grace and gift so that this study could be conducted smoothly. This study was carried out thanks to the support and guidance from various parties. For that, we express our deepest 
gratitude to all parties who have provided moral and material assistance.

1. Our gratitude to the Ministry of Research, Technology and Higher Education for funding this study.

2. Our gratitude to Prof Soekidjo Notoadmodjo as Rector of $\mathrm{MH}$. Thamrin University.

3. Our gratitude to our Dean and staff of MH. Thamrin University

4. Our gratitude for Heads of the study program at the Faculty of Health, $\mathrm{MH}$ Thamrin University.

5. Our gratitude to our students and enumerators.

We realize that this study is far from perfect; for this reason, we look forward to constructive criticism and suggestions for the perfection of this journal. Finally, we hope that this journal can be useful for readers in general and us in particular.

\section{Refrences}

[1] https://www.beritasatu.com/keseh atan/535688/prevalensi-kanker-diindonesia-meningkat.diunduh pada hari Rabu 11 Desember 2019 Pukul $21.00 \mathrm{wib}$

[2] Mboi, N. Panduan Praktik Klinis Bagi Dokter di Fasilitas Pelayanan Kesehatan Primer. Menteri Kesehatan Republik Indonesia. 2014.

[3] Olfah, Y., Mendri, N. K., \& Badi'ah, A.Kanker Payudara \& Sadari(pertama). yogyakarta: Nuha Medika. 2013.

[4] Tarmi. Hubungan pengetahuan dan informasi dengan prilaku SADARI di MTS mathla'ul anwar kota tangerangtahun 2015, Jurnal komunikasi kesehatan. 2017.

[5] Susanti, Ninik dkk. Gambaran Tingkat Pengetahuan Mahasiswa Semester II Tentang SADARI (Pemeriksaan Payudara Sendiri) di Prodi DIII Keperawatan Stikes PKU Muhamadiah Surakarta. 2012. Volume 10/September 3013Feb 2014

[6] Fitriyanti, Lia. Determinan Praktek Pemeriksaan Payudara Sendiri
(SADARI) Pada Mahasiswi Sekolah Tinggi Ilmu Kesehatan di Jakarta Timur Tahun 2013. Thesis. URINDO. 2013.

[7] Susanti, Rosa. Faktor-faktor yang Berhubungan Dengan Prilaku SADARI pada Dosen di Fakultas Kesehatan Universitas Mohammad Husni Thamrin Tahun 2014. 2014. Volume 6, No. 2,

[8] Ekanita. Hubungan Antara Pengetahuan Dan Sikap WUS Terhadap Perilaku Pemeriksaan Payudara Sendiri (Sadari). Jurnal Kesehatan Masyarakat. 2013.

[9] Imeldyanti, Auvyka. Hubungan Pengetahuan Sikap Remaja Putri Terhadap Prilaku SADARI di SMU 2 Pasar Kemis Kabupaten Tangerang tahun 2010. Skripsi. 2010.

[10] Sugiyanti D, Widyawati SA, T. A. Beberapa Faktor yang Berhubungan dengan Perilaku Pmeriksaan Payudara Sendiri (SADARI) pada Wanita di Desa Tambak Agung Kecamatan Kaliori Kabupaten Rembang. 2013.

[11] Septiani, S. \& Suara, M. Faktor Faktor Yang Berhubungan Dengan Perilaku Pemeriksaan Payudara Sendiri ( Sadari ) Pada Siswa SMAN 62 Jakarta 2012.

[12] Suralaga, Cholis. Faktor - Faktor Yang Berhubungan Dengan Praktek SADARI Pada Siswa Sekolah Menengah Pertama, Jakarta. URINDO. 2012.

[13] Gusti Ayu Resa Dyanti, dkk.Faktor-Faktor Keterlambatan Penderita Kanker Payudara Dalam Melakukan Pemeriksaan Awal Ke Pelayanan Kesehatan. 2016. 